\title{
Perancangan dan Pembangunan Sistem Distribusi Air Bersih
}

\author{
Cecep Deni Mulyadi ${ }^{1}$, Muhammad Ubay Caraka ${ }^{2 *}$ \\ ${ }^{1,2}$ Program Studi Teknik Mesin, Fakultas Teknik, Universitas Sangga Buana YPKP Bandung \\ 1,2JI. PH.H. Mustofa No. 68, Cikutra, Cibeunying Kidul, Kota Bandung, 40124, Indonesia \\ E-mail: denicecep30@gmail.com ${ }^{1}$, ubaycm3@email.com²
}

\section{Info Naskah:}

Naskah masuk: 22 Oktober 2020

Direvisi: 17 Maret 2021

Diterima: 23 Agustus 2021

\begin{abstract}
Abstrak
Air sangat berguna bagi setiap manusia maupun mahluk hidup. Salah satunnya di terapkan pengunaan air pada gedung dengan cara sistem pepipaan . Dengan adanya kebutuhan tersebut perlu ada nya perhitungan akan kebutuhan air bersih dan pengelolaan air pada gedung tersebut sehingga sistem efektif dan efisien dengan menggunakan sistem plambing. Metode yang digunakan pada penelitian perpipaan gedung ini yaitu menghitung dari berbagai sisi seperti pemilihan kapasitas penampungan air bersih, pemilihan pompa dan sistem perpipaannya harus disesuaikan dengan kebutuhan di gedung akademik, penting untuk dimengerti besar kapasitas, diameter pipa dan head instalasi. Dari hasil perhitungan didapatkan kapasitas aliran sebesar 1,56 m³/menit, dengan kapasitas tangki air bawah sebesar 84 $\mathrm{m}^{3} /$ hari dalam waktu operasional selama 8 jam dalam satu hari. Kapasitas tangki air atap sebesar $15 \mathrm{~m}^{3}$ yang sanggup melayani beban kebutuhan puncak penggunaan air bersih selama 30 menit. Sedangkan head total instalasi adalah sebesar 30 meter, sehingga dipilih jenis pompa sentrifugal dengan putaran $3000 \mathrm{rpm}$, frekuensi $50 \mathrm{~Hz}$, daya motor $15 \mathrm{KW}$.
\end{abstract}

Keywords:

plumbing;

capacity;

pump head.

\begin{abstract}
Water is one of the natural resources that is very useful for every living thing. Water demand of human will increase in accordance with technological developments that occur in the community, with an effective and efficient regulatory and processing system using plumbing systems. The clean water distribution system in an academic building can work if it is supported by a system of clean water storage that is in accordance with the needs and supported by a pump installation system and piping installation. In the selection of water storage capacity, the selection of pumps and piping systems must be adjusted to the needs of the academic building, it is important to understand the capacity, pipe diameter and installation head. From the calculation results obtained a flow capacity of $1.56 \mathrm{~m}^{3} /$ minute with a water tank capacity of 84 $\mathrm{m}^{3} /$ day in 8 hours of operational time in one day. A roof water tank capacity of 15 $\mathrm{m}^{3}$ that is able to serve the peak needs of clean water for 30 minutes. While the total head of the installation is 30 meters, so that the selected type of centrifugal pump with a rotation of $3000 \mathrm{rpm}$, frequency $50 \mathrm{~Hz}$, motor power $15 \mathrm{KW}$.
\end{abstract}




\section{Pendahuluan}

Air sangat lah penting bagi manusia maupun mahluk hidup.salah satu pengunaan air pada kebutuhan manusia adalah kebutuhan air pada gedung. Yang mana pembangunan gedung-gedung banyak di lakukan, maka perlu dibuat suatu sistem perpipaan guna menyalurkan air bersih ke tiap unit beban, sehingga pemakai dapat menggunakan air sesuai dengan yang dibutuhkan. Contoh sistem penyediaan air bersih diperlihatkan pada Gambar 1, Gambar 2 dan Gambar 3 diantaranya adalah sistem tangki atap, sistem sambungan langsung dan sistem booster Gedung.

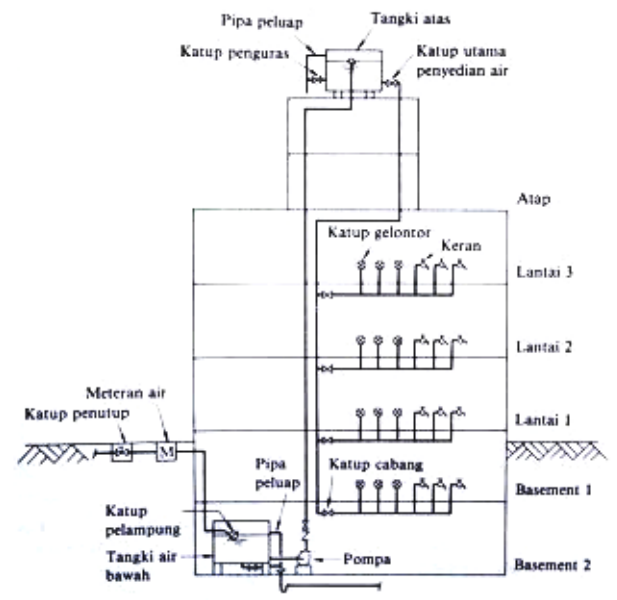

Gambar 1. Contoh Sistem Distribusi Air Bersih Dengan Tangki Atap [1]

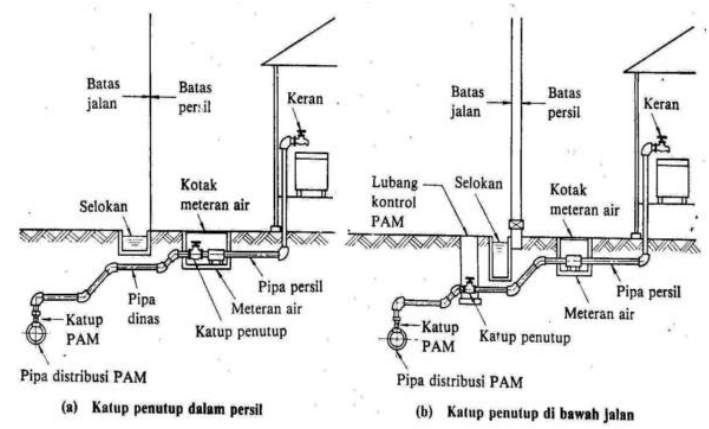

Gambar 2. Contoh Sistem Distribusi Air Bersih Dengan Sambungan Langsung [2]

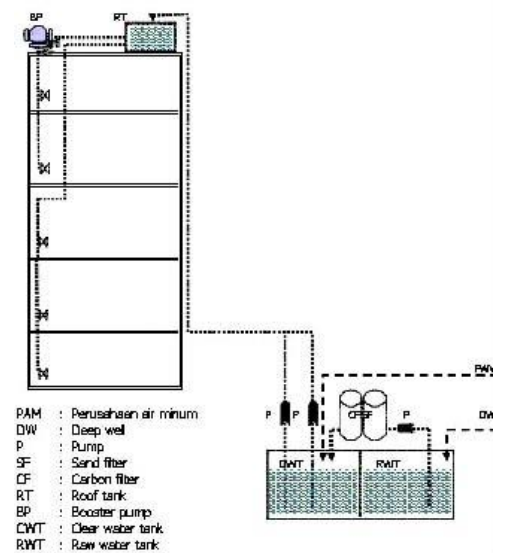

Gambar 3. Contoh Sistem Distribusi Air Bersih Dengan Pompa Booster [3]
Terdapat beberapa metode dalam penaksiran penyediaan kebutuhan air, yaitu yang berdasarkan pada penaksiran Berdasarkan Pemakaian Air Rata-Rata Perorang Setiap Hari. Metode ini digunakan apabila jumlah penghuni atau pengguna gedung dapat diketahui. Melalui perkiraan jumlah pemakaian air rata-rata sehari dalam jangka waktu operasional gedung tertentu.

Metode lainnya adalah penaksiran berdasarkan jenis dan jumlah alat plambing. Metode dengan mengetahui alat plumbing, dan mengetahui jumlah jenis alat dalam gedung tersebut. Metode lain adalah penaksiran Berdasarkan Unit Beban Alat Plambing (UBAP). Metode menyatakan setiap alat plambing dalam unit beban (fixture unit).

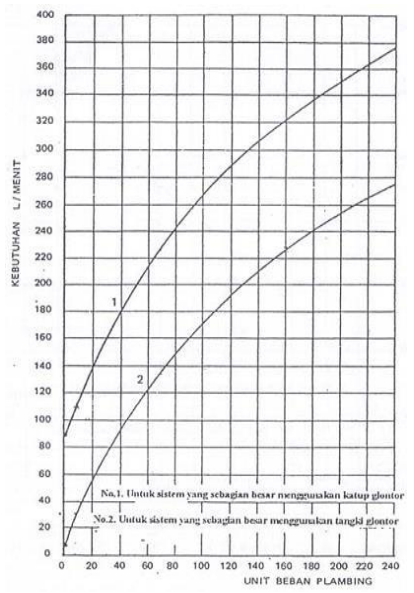

Gambar 4. Kurva Hubungan Unit Beban Alat Plambing Dengan Laju Aliran 0-240 [4]

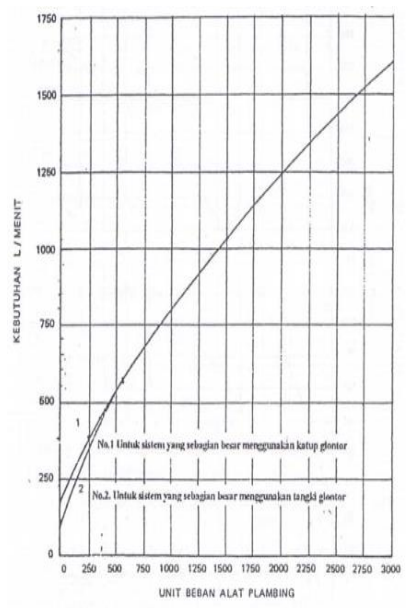

Gambar 5. Kurva Hubungan Unit Beban Alat Plambing Dengan Laju Aliran 0-3000 [5]
Permasalahan pada penelitian ini adalah berlatar belakang bahwa sistem pemipaan merupakan sistem jaringan pipa yang terpasang untuk menyalurkan fluida. Pompa adalah alat yang digunakan untuk memindahkan fluida sesuai dengan yg dibutuhkan pada sistem pemipaan. Kavitasi akan terjadi apabila terjadi tekanan yang kurang di bawah tekanan uap jenuh.

Tujuan dari penelitian ini adalah mengusulkan sebuah perancangan dan pembangunan sistem distribusi air bersih. Cara yang dilakukan adalah dengan menghitung jumlah air yg di perlukan yang di simpan di tangki

\section{Metode}

Tahapan dalam penelitian ini diperlihatkan pada Gambar 6. Karena belum diketahui jumlah penghuni dalam gedung, maka penaksiran kebutuhan air bersih dalam perhitungan ini digunakan dengan 2 metode, yaitu: metode jenis dan jumlah alat plambing, serta metode unit beban alat plambing. Dari metode diatas dapat ketahui perbedaannya yang akan digunakan untuk kebutuhan air yang terbesar.

Berdasarkan denah lantai Gedung Akademik yang dirancang akan direncanakan memiliki 4 lantai, yang dimana masing-masing lantai berfungsi sebagai berikut:

a) Lantai dasar: exhibition hall, perpusatakaan, ruang pimpinan akademik 
b) Lantai dua: musholla, ruang skretariat akademik, ruang dosen \& ruang laboratorium

c) Lantai tiga: ruang pusat study, ruang seminar atau ruang sidang

d) Lantai empat: ruang pusat study dan ruang serbaguna

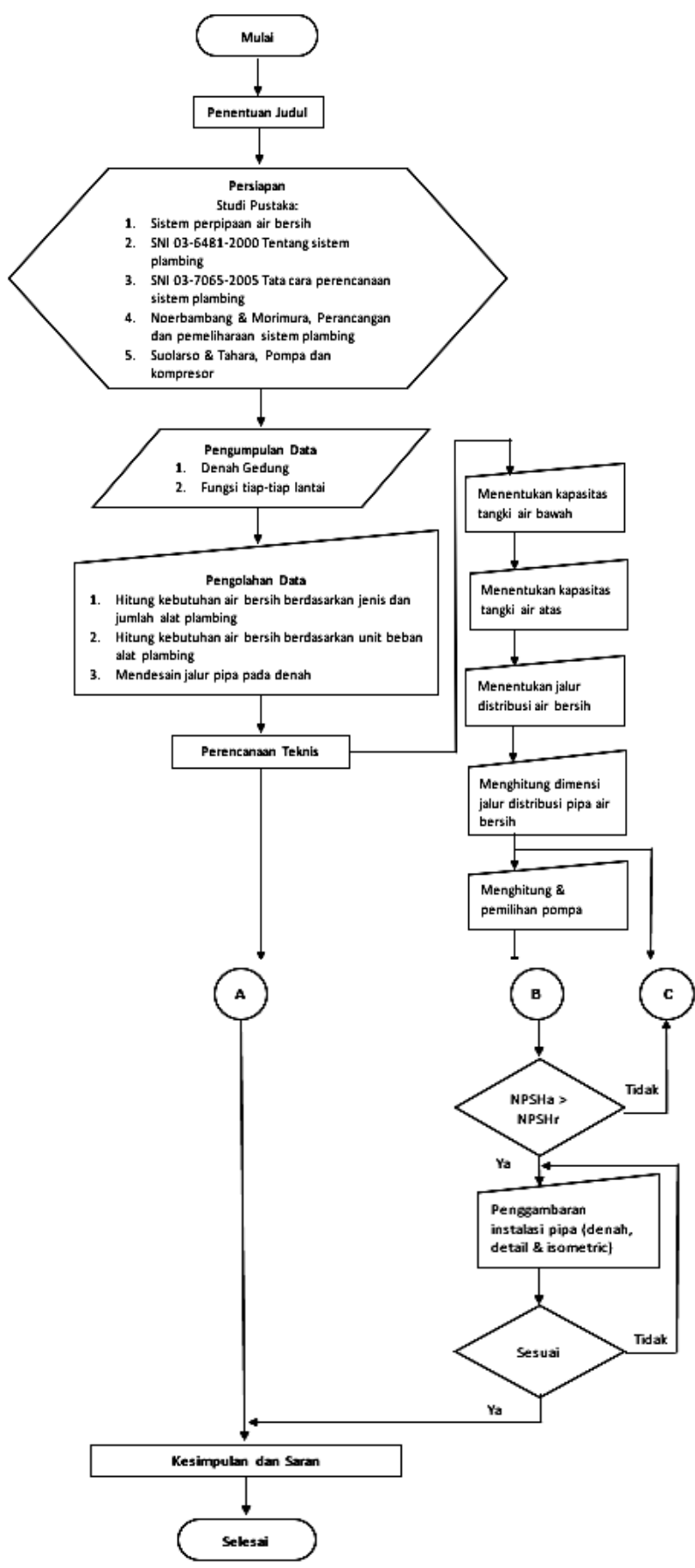

\section{Hasil dan Pembahasan}

\subsection{Perhitungan Kebutuhan Air Bersih}

Untuk menghitung kebutuhan air bersih menurut jenis dan alat plambing jumlah pemakaian air di gedung akademik di dapat 14880 liter/jam, berdasarkan jenis dan jumlah alat plambing [7].

Pemakaian air bersih per jam $(Q h)$ :

$$
\begin{aligned}
Q h \quad & =14880 \text { liter/jam } \\
& =\mathbf{1 4 , 8 8} \mathbf{~ m}^{\mathbf{3}} / \mathbf{j a m}
\end{aligned}
$$

Penggunaan air bersih rata-rata sehari $(Q d)$ :

$$
Q d=Q h \times \mathrm{T}
$$

Dimana:

Qd = Pemakaian air rata-rata sehari $\left(\mathrm{m}^{3} / \mathrm{hari}\right)$

$Q h \quad=$ Pemakaian air rata-rata per jam $\left(\mathrm{m}^{3} / \mathrm{jam}\right)$

$T \quad$ = Jangka waktu pemakaian (jam)

Maka:

Qd $=Q h \times \mathrm{T}$

$=14,88 \mathrm{~m}^{3} / \mathrm{jam} \times 8 \mathrm{jam} / \mathrm{hari}$

$=119,04 \mathrm{~m}^{3} /$ hari

Penggunaan air bersih pada jam puncak ( $Q$ h maks):

$Q h$ maks $=Q h \times C 1$

Dimana:

Qh maks = Pemakaian air jam puncak $\left(\mathrm{m}^{3} / \mathrm{jam}\right)$

$\mathrm{C} 1=$ koefisien pemakaian air pada jam puncak (berkisar antara 1,5 - 2) (ref. Soufyan \& Morimura). Direncanakan C1 = 1,5 maka:

Qh maks $=Q h \times \mathrm{C} 1$

$$
=14,88 \mathrm{~m}^{3} / \mathrm{jam} \times 1,5
$$$$
=22,32 \mathrm{~m}^{3} / \mathrm{jam}
$$

Penggunaan air bersih pada menit puncak ( $Q m$ maks):

$Q m$ maks $=C 2 \times(\mathrm{Qh}: 60)$

Dimana:

Qm maks $=$ Pemakaian air menit puncak $\left(\mathrm{m}^{3} / \mathrm{menit}\right)$

Qh = Pemakaian air rata-rata per jam $\left(\mathrm{m}^{3} / \mathrm{jam}\right)$

C2 = koefisien pemakaian air pada menit puncak (berkisar antara 3 - 4) (ref. Soufyan \& Morimura). Direncanakan C2 $=3$, sehingga:

Qm maks $=C 2 \times(\mathrm{Qh}: 60)$ $=3 \times\left(14,88 \mathrm{~m}^{3} / \mathrm{jam}: 60\right)$

$=0,744 \mathrm{~m}^{3} /$ menit

Dari hasil perhitungan jumlah unit beban alat plambing yang di butuhkan didapatkan nilai 487,5 selanjutnya penulis hubungkan dengan kurva unit beban alat plambing dengan laju aliran sebagaimana pada Gambar 7 yang mana sebagian besar menggunakan sistem tangki gelontor diwakilkan pada angka 1.

Gambar 6. Diagram Alir [6] 


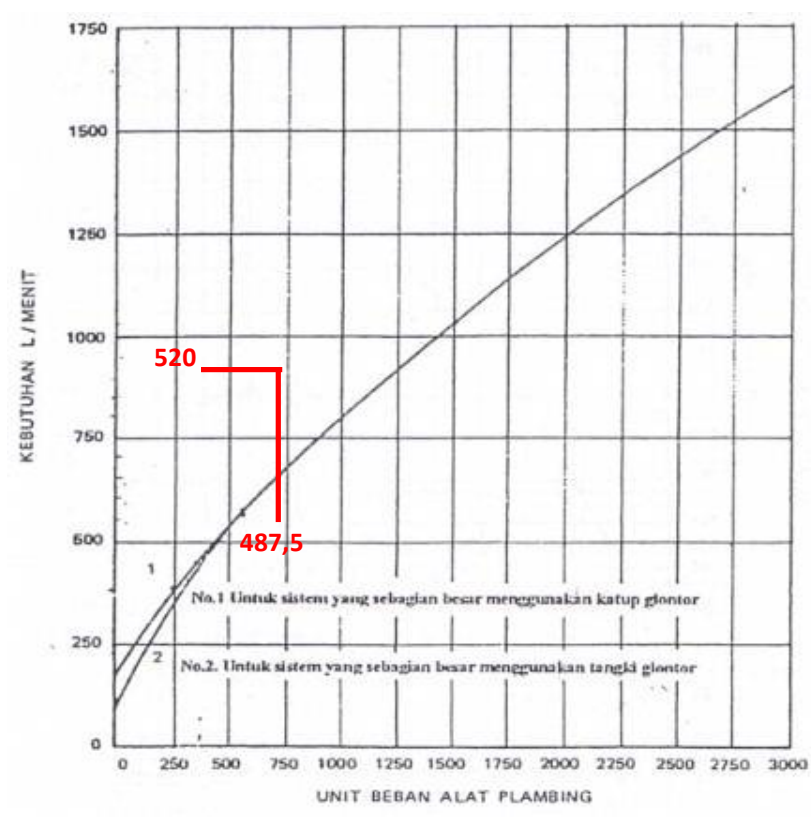

Gambar 7. Diagram Alir [7].

$Q m=520$ liter $/$ menit

$=0,52 \mathrm{~m}^{3} /$ menit

Penggunaan air bersih per jam $(Q h)$ :

$Q h=Q m \times(60$ menit $: 1$ jam $)$

Dimana:

Qh = Pemakaian air rata-rata per jam $\left(\mathrm{m}^{3} / \mathrm{jam}\right)$

$Q m \quad=$ Pemakaian air rata-rata per menit $\left(\mathrm{m}^{3} / \mathrm{menit}\right)$

Maka:

Qh $=Q m \times(60$ menit $: 1$ jam $)$

$=0,52 \mathrm{~m}^{3} /$ menit $\times 60$ menit

$=31,2 \mathrm{~m}^{3} / \mathbf{j a m}$

Pengunaan air bersih rata-rata sehari $(Q d)$ :

$Q d=Q h \times T$

Dimana:

Qd = Pemakaian air rata-rata sehari $\left(\mathrm{m}^{3} / \mathrm{hari}\right)$

$Q h \quad=$ Pemakaian air rata-rata per jam $\left(\mathrm{m}^{3} / \mathrm{jam}\right)$

$T=$ Jangka waktu pemakaian (jam)

Maka:

Qd $=Q h \times T$

$=31,2 \mathrm{~m}^{3} / \mathrm{jam} \times 8 \mathrm{jam}$

$=250 \mathrm{~m}^{3} / \mathrm{hari}$

Penggunanaan air bersih pada jam puncak ( $Q$ h maks):

$Q h$ maks $=Q h \times C 1$

(6)

Dimana:

Qh maks = Pemakaian air jam puncak $\left(\mathrm{m}^{3} / \mathrm{jam}\right)$

Qh = Pemakaian air rata-rata per jam $\left(\mathrm{m}^{3} / \mathrm{jam}\right)$

$C 1=$ koefisien pemakaian air pada jam puncak

(berkisar antara 1,5 - 2) (ref. Soufyan \&

Morimura). Direncanakan C1 = 1,5

maka:

Qh maks $=Q h \times C 1$

$=31,2 \mathrm{~m}^{3} / \mathrm{jam} \times 1,5$
$=\mathbf{4 6 , 8} \mathbf{~ m}^{3} / \mathbf{j a m}$
Penggunaan air bersih pada menit puncak (Qm maks):

$Q m$ maks $=C 2 \times(Q h: 60)$

Dimana:

Qm maks = Pemakaian air menit puncak $\left(\mathrm{m}^{3} /\right.$ menit $)$

$Q m=$ Pemakaian air rata-rata per menit ( $\mathrm{m}^{3} /$ menit)

C2 = koefisien pemakaian air pada menit puncak (berkisar antara 3 -4) (ref. Soufyan \& Morimura). Direncanakan C2 $=3$

maka:

$Q m$ maks $=C 2 \times(Q h: 60)$

$$
=3 \times\left(31,2 \mathrm{~m}^{3} / \mathrm{jam}: 60\right)
$$

$=1,56 \mathrm{~m}^{3} /$ menit

Perbandingan penaksiran kebutuhan air bersih terhadap 2 metode diatas dapat disimpulkan dalam Tabel 1.

Tabel 1. Perbandungan Penaksiran Kebutuhan Air Bersih Terhadap 2 Metode Perhitungan [9].

\begin{tabular}{|c|c|c|c|c|c|}
\hline Metode & $\begin{array}{c}\text { Qd } \\
\left(\mathbf{m}^{3} / \text { hari }\right)\end{array}$ & $\begin{array}{c}\text { Qh } \\
\left(\mathbf{m}^{3} / \mathrm{hari}\right)\end{array}$ & $\underset{\left(\mathbf{m}^{3} / \text { hari }\right)}{\mathbf{Q m}}$ & $\begin{array}{c}\text { Qh-maks } \\
\left(\mathbf{m}^{3} / \mathbf{j a m}\right) \\
\mathrm{C}=1,5\end{array}$ & $\begin{array}{c}\text { Qm-maks } \\
\left(\mathbf{m}^{3} / \text { menit }\right) \\
\text { C2 }=3\end{array}$ \\
\hline $\begin{array}{l}\text { Berdasar } \\
\text { kan jenis } \\
\text { dan } \\
\text { jumlah } \\
\text { alat } \\
\text { plambing }\end{array}$ & 119,04 & 14,88 & 0,24 & 22,32 & 0,75 \\
\hline $\begin{array}{l}\text { Berdasar } \\
\text { kan unit } \\
\text { beban } \\
\text { plambing }\end{array}$ & 250 & 31,2 & 0,52 & 46,8 & 1,56 \\
\hline
\end{tabular}

3.2. Perhitungan Kapasitas Tangki Air

a. Volume Tangki Air Bawah (Ground Water Tank)

$V r \quad=Q d-(Q s \times T)$

Dimana:

Vr = Kapasitas tangki air bawah $\left(\mathrm{m}^{3} /\right.$ hari $)$

Qd $\quad=$ Pemakaian air rata-rata sehari $\left(\mathrm{m}^{3} /\right.$ hari $)$

Qs $\quad=$ Kapasitas pipa Dinas $\left(\mathrm{m}^{3} / \mathrm{jam}\right)$

$Q h \quad=$ Pemakaian air rata-rata per jam $\left(\mathrm{m}^{3} / \mathrm{jam}\right)$

Jika dianggap kapasitas pengaliran pipa dinas $(Q s)$ sebesar dua pertiga dari kebutuhan air rata-rata perjam, maka diperoleh:

$$
\text { Qs } \quad \begin{aligned}
& =\frac{2}{3} \times Q h \\
& =\frac{2}{3} \times 31,2 \mathrm{~m}^{3} / \mathrm{jam} \\
& =\mathbf{2 0 , 8} \mathbf{~ m}^{3} / \mathbf{j a m}
\end{aligned}
$$

Sehingga volume tangki air bawah:

$$
\begin{aligned}
V r & =Q d-(Q s \times T) \\
& =250 \mathrm{~m}^{3} / \text { hari }-\left(20,8 \mathrm{~m}^{3} / \mathrm{jam} \times 8 \mathrm{jam}\right) \\
& =\mathbf{8 3 , 6} \mathbf{~ m}^{\mathbf{3}} \approx \mathbf{8 4} \mathbf{~ m}^{\mathbf{3}}
\end{aligned}
$$

(dimensi tangki air bawah $=7 \times 8 \times 1,5$ ) 
b. Volume Tangki Air Atas (Roof Water Tank)

$V e=((Q p-Q m a k s) \times T p)-(Q p u \times T p u)$

Dimana:

Ve $\quad=$ Volume efektif tangki atas $\left(\mathrm{m}^{3}\right)$

$Q p \quad=$ Kebutuhan puncak $\left(\mathrm{m}^{3} /\right.$ menit $)=$ Qm maks

$Q$ maks $=$ Kebutuhan jam puncak $\left(\mathrm{m}^{3} / \mathrm{jam}\right)$

Qpu $\quad=$ Qmaks

Tp = Perkiraan jangka waktu kebutuhan puncak (menit) $=30$

Tpu = Jangka waktu kerja pompa pengisi (menit) $=$ $10-15$ menit

Sehingga:

Ve $=((Q p-Q$ maks $) \times T p)-(Q p u \times T p u)$

$=\left(\left(1,56 \mathrm{~m}^{3} /\right.\right.$ menit $-0,78 \mathrm{~m}^{3} /$ menit $) \times 30$ menit $)-$ $\left(0,78 \mathrm{~m}^{3} /\right.$ menit $\times 10$ menit $)$

$=23,4 \mathrm{~m}^{3} /$ menit $-7,8 \mathrm{~m}^{3} /$ menit

$=15,6 \mathrm{~m}^{3} \approx 15 \mathrm{~m}^{3}$

(dimensi tangki air atas $=2 \times 5 \times 1,5$ )

\subsection{Perencanaan Dimensi Pipa}

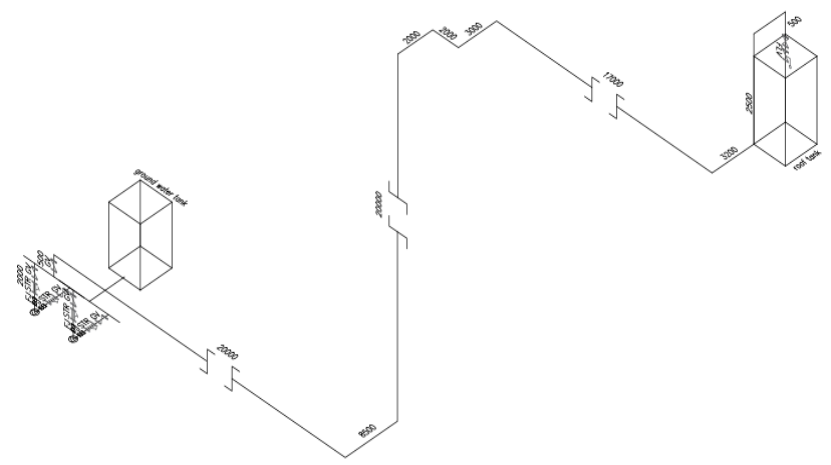

Gambar 8. Gambar Instalasi Pompa Utama [7]

$$
\mathrm{Q} \quad=\frac{\mathrm{v} \times \pi \times \mathrm{D}^{2}}{4}
$$

Dimana :

$\mathrm{Q}=$ Kapasitas aliran $(\mathrm{m} 3 / \mathrm{jam})$

$\mathrm{D} \quad=$ Diameter dalam pipa $(\mathrm{m})$

$\mathrm{v} \quad=$ Kecepatan aliran $(\mathrm{m} /$ detik $)$, diasumsikan $=$ 2 meter/detik

Sehingga:

Q $\quad=\left(\mathrm{v} \times \pi \times \mathrm{D}^{2}\right) / 4$

$46,8 \mathrm{~m}^{3} / \mathrm{jam}=\frac{2 \mathrm{~m} / \operatorname{detik} \times 3,14 \times \mathrm{D}^{2}}{4}$

$\mathrm{D}^{2}$

$=\frac{46,8 \mathrm{~m}^{3} / \mathrm{jam} \times 4}{2 \times 3600 \times 3,14}$

$\mathrm{D}^{2} \quad=\frac{187,2}{22608}$

$\mathrm{D} \quad=\sqrt{0,008280}$

$\mathrm{D} \quad=0,090$ meter
$\begin{array}{ll}\mathrm{D} & =0,090 \times \frac{1000}{25,4} \\ \mathrm{D} & =3,63^{\prime \prime} \approx 4^{\prime \prime}\end{array}$

Maka dipilih pipa PVC dengan diameter nominal $(\mathrm{NPS})=4$ " atau sama dengan $114,3 \mathrm{~mm}$ dan inside diameter (ID) $=102,3 \mathrm{~mm}$. Dari hasil perhitungan diatas, maka kecepatan aliran didalam pipa sebenarnya adalah:

Q

$$
\begin{aligned}
& =\frac{\mathrm{v} \times \pi \times \mathrm{D}^{2}}{4} \\
& =\frac{4 \times \mathrm{Q}}{\pi \times \mathrm{D}^{2}}
\end{aligned}
$$

$\mathrm{V}$

$$
=\frac{4 \times 46,8 \mathrm{~m}^{3} / \mathrm{jam}}{3,14 \times\left(4^{\prime \prime} \times 25,4 / 1000\right)^{2}}
$$

$\mathrm{V}$

$$
=\frac{187,2}{3,14 \times(0,1016 \mathrm{~m})^{2}}
$$

V

$$
=5775,489 \text { meter } / \text { jam }
$$$$
\text { = 1, } 60 \text { meter } / \text { detik }
$$

Sebelum mencari head loss mayor (kerugian yang terjadi didalam pipa), terlebih dahulu mencari tipe aliran yang terjadi didalam pipa tersebut. Sebagai acuan apakah suatu aliran itu laminer atau turbulen dipakai bilangan reynold:

- Pada $\operatorname{Re}<2300$, aliran laminer

- $\quad$ Pada $\operatorname{Re}>4000$, aliran turbulen

Pada $\operatorname{Re}=2300-4000$, maka terdapat daerah transisi, pada kondisi pipa dan aliran.

$\operatorname{Re} \quad=(\mathrm{v} \times \mathrm{D}): v$

Dimana:

$\mathrm{Re} \quad=$ Bilangan reynolds (tidak berdimensi)

$\mathrm{V} \quad=$ Kecepatan rata-rata aliran didalam pipa (meter/detik).

$\mathrm{D} \quad=$ Diameter dalam pipa (meter)

$v \quad=$ Viskositas air $=1,004 \times 10^{-6} \mathrm{~meter}^{2} /$ detik

maka:

$\operatorname{Re} \quad=(\mathrm{v} \times \mathrm{D}): v$

$=(1,60$ meter/detik $\times 0,1023$ meter $): 1,004 \times 10^{-6}$

$=163027,888=1 \times 10^{5}$

Dari hasil perhitungan diatas, $\operatorname{Re}>4000$ (aliran bersifat turbulen). Material pipa yang digunakan adalah pipa PVC dengan relative roughness 0,0025 , dimana untuk pipa diameter 4" nilai relative roughness (e/D) adalah 0,0025 . Dari moody diagram didapatkan harga (f) dari pipa tersebut adalah 0,026. 


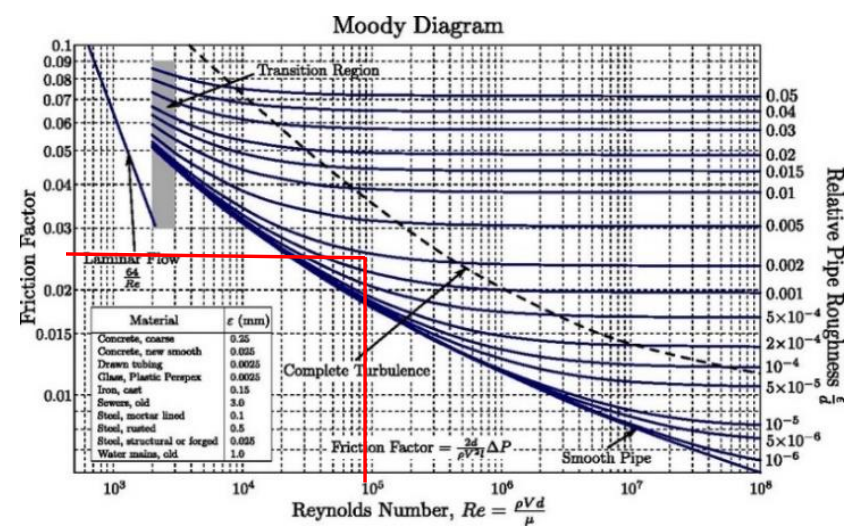

Gambar 9. Moody Diagram [8]

Sehingga kerugian gesek yang terjadi didalam pipa adalah:

$$
\text { hf } \quad=f \times(L: 2 . D) \times\left(v^{2}: 2 . g\right)
$$

\section{Dimana:}

$$
\begin{array}{ll}
\mathrm{hf} & =\text { Head kerugian gesek dalam pipa }(\mathrm{m}) \\
\mathrm{f} & =\text { Friction factor } \\
\mathrm{L} & =\text { Panjang pipa }(\mathrm{m}) \\
\mathrm{D} & =\text { Diameter dalam pipa }(\mathrm{m}) \\
\mathrm{V} & =\text { Kecepatan aliran }(\mathrm{m} / \text { detik })=1,60 \text { meter } / \text { detik } \\
\mathrm{g} & =\text { Percepatan gravitasi }\left(9,8 \text { meter } / \text { detik }^{2}\right)
\end{array}
$$

Maka:

$$
\begin{aligned}
\mathrm{hf} \quad & \mathrm{f} \times(\mathrm{L}: 2 . \mathrm{D}) \times\left(\mathrm{v}^{2}: 2 . \mathrm{g}\right) \\
& =0,025 \times(80 /(2 \times 0,1023)) \times\left(1,60^{2} /(2 \times 9,8)\right) \\
& =0,026 \times 391,006 \times 0,130 \\
& =\mathbf{1 , 2 7 0} \text { meter }
\end{aligned}
$$

Kerugian gesek yang ditimbulkan karena adanya fitting. Nilainya dapat diketahui melalui persamaan berikut:

$$
h e=f \times \frac{V^{2}}{2 . g}
$$

\section{Dimana:}

$$
\begin{array}{ll}
\text { he } & =\text { Head loss minor } \\
f & =\text { Koefisien kerugian gesek fitting dan aksesoris } \\
\text { pipa } & \\
V & =\text { Kecepatan aliran }(\mathrm{m} / \text { detik })=1,60 \text { meter } / \text { detik } \\
g & =\text { Percepatan gravitasi }\left(9,8 \text { meter } / \text { detik }^{2}\right)
\end{array}
$$

Dari masing-masing aksesoris memiliki koefisien kerugian gesek yang berbeda-beda, [11]. Fitting dan aksesoris yang terdapat disepanjang pipa distribusi seperti pada Tabel 2 .

Tabel 2. Koefisien Kerugian Gesek Dari Berbagai Katup [12]

\begin{tabular}{lcc}
\hline \multicolumn{1}{c}{ Deskripsi } & Quantity & $\begin{array}{c}\text { Koefisien kerugian } \\
\text { gesek }\end{array}$ \\
\hline gate valve & 2 buah & $@ 0,14$ \\
strainer & 1 buah & 0,9 \\
flexible Joint & 2 buah & 1,7 \\
Check valve & 1 buah & 7,3 \\
elbow $90^{\circ}$ & 11 buah & $@ 1,129$ \\
\hline
\end{tabular}

Maka head loss minor pipa distribusi adalah:

he

$$
\begin{aligned}
= & f \times\left(V^{2}: 2 . g\right) \\
= & ((0,14 \times 2)+0,9+(1,7 \times 2)+7,3+(1,129 \times 11)) \\
& \times\left(1,60^{2}: 2 \times 9,8\right) \\
= & 24,299 \times 0,130 \\
= & \mathbf{3 , 1 5 8} \text { meter }
\end{aligned}
$$

Sehingga total head loss pipa distribusi adalah:

$$
\begin{aligned}
\text { hl } & =\mathrm{hf}+\text { he } \\
& =1,270 \text { meter }+3,158 \text { meter } \\
& =\mathbf{4 , 4 2 8} \text { meter }
\end{aligned}
$$

\subsection{Perhitungan dan Pemilihan Pompa}

Dalam menghitung Head Total Pompa

$$
H \quad=h_{\mathrm{a}}+\Delta h p+h^{\mathrm{l}}+\frac{\mathrm{v}^{2}}{2 g}
$$

Dimana:

$H \quad=$ Head total pompa $(\mathrm{m})$

$h_{\mathrm{a}} \quad=$ Head statis total $(\mathrm{m})$, perbedaan tinggi antara titik inlet dan outlet ( 25 meter)

$\Delta h p \quad=$ Perbedaan tekanan yang bekerja pada kedua permukaan air (m)

$h^{\mathrm{l}} \quad=$ Berbagai kerugian head pipa, katup, belokan sambungan, dll. (m)

$V \quad=$ Kecepatan aliran $(\mathrm{m} /$ detik $)$, diasumsikan $=2$ meter/detik

$g=\quad=$ Percepatan gravitasi $\left(9,8\right.$ meter/detik $\left.{ }^{2}\right)$

Maka:

$$
\begin{array}{ll}
H & =h_{\mathrm{a}}+\Delta h p+h^{\mathrm{l}}+\frac{\mathrm{v}^{2}}{2 g} \\
H & =25+0+4,428+\frac{1,60^{2}}{2 \times 9,8} \\
H & =25+0+4,428+0,130 \\
H & =29, \mathbf{5 5 8} \text { meter } \approx \mathbf{3 0} \text { meter }
\end{array}
$$

Pertimbangan dalam pemilihan suatu jenis pompa adalah berdasarkan head dan kapasitas yang telah diketahui, seperti pada Gambar 10. Pada Gambar 11 untuk kondisi Qm maks $=1,56 \mathrm{~m}^{3} /$ menit atau sama dengan 412,10 USGpm dan $\mathrm{H}=30$ meter atau sama dengan $98,425 \mathrm{ft}$, maka pompa yang adalah jenis sentrifugal. Setelah diketahui kapasitas pompa, head pompa dan jenis pompa, maka pemilihan pompa standar bisa menggunakan diagram pemilihan pompa standar. 


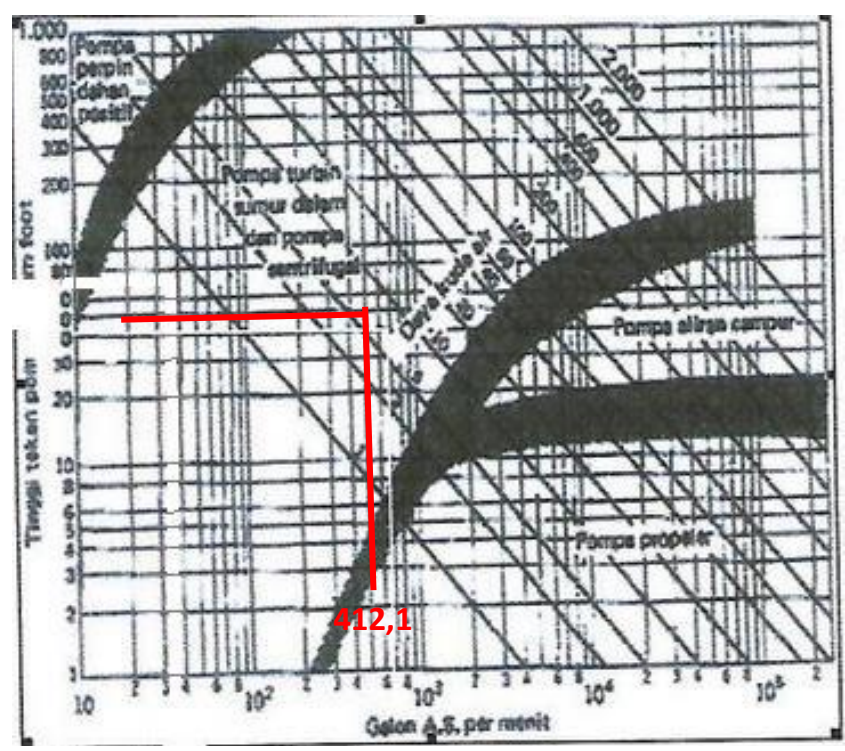

Gambar 10. Diagram Pemilihan Pompa [12]

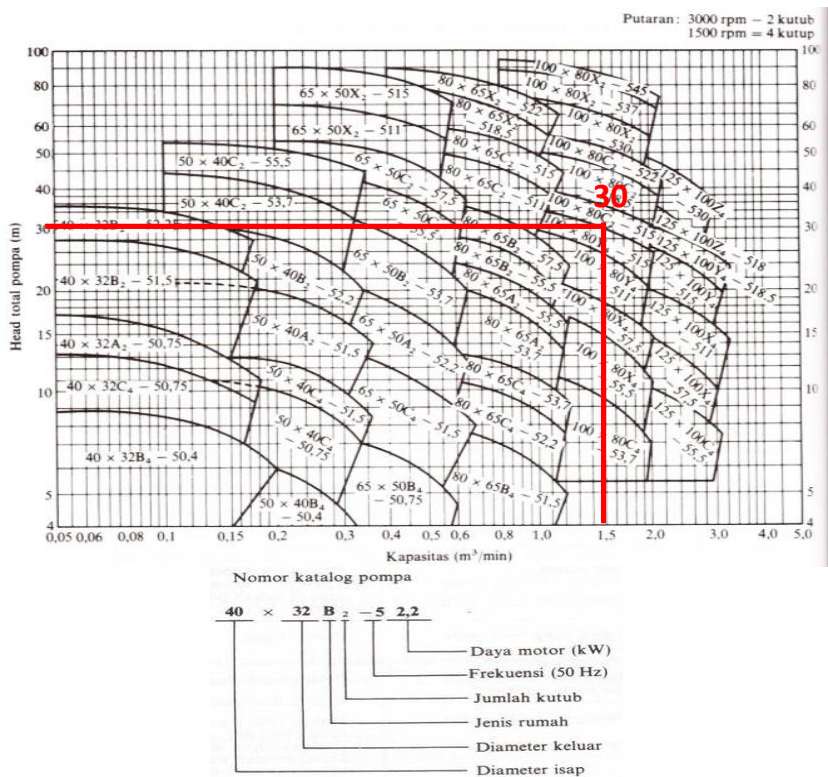

Gambar 11. Diagram Pemilihan Pompa [11]

Berdasarkan diagram pemilihan pompa standar maka dipilih, 100 x 80 C2 - 5 15. Arti dari kode tersebut adalah:
- $100=$ diameter hisap $(\mathrm{mm})$
- $80=$ diameter buang $(\mathrm{mm})$
- $\mathrm{C}=$ type rumah
- Jumlah kutub (n) = 2, (3000 rpm)
- $5=$ frekuensi $(50 \mathrm{~Hz})$
- Daya Motor $=15 \mathrm{~kW}$

\subsection{Perhitungan Kavitasi}

Kavitasi akan terjadi bila tekanan statis suatu aliran zat cair turun sampai dibawah tekanan uap jenuhnya.

Net positive suction head available (NPSHa)

$N P S H a=(P a: \Upsilon)-(P v: \Upsilon)-h s-h l$
Dimana:

$N P S H a=$ NPSH yang tersedia pada instalasi $(\mathrm{m})$

$\mathrm{Pa}=$ Tekanan atmosfir $\left(\mathrm{kgf} / \mathrm{m}^{2}\right)$

$\Upsilon=$ Berat zat cair per satuan volume $\left(\mathrm{kgf} / \mathrm{m}^{2}\right)$

$P v \quad=$ Tekanan uap jenuh $\left(\mathrm{kgf} / \mathrm{m}^{2}\right)$

hs $\quad=$ Head hisap statis $(\mathrm{m})$

$h l \quad=$ Total head loss pipa distribusi $(\mathrm{m})$

Nilai $P a, \gamma$ dan $P v$ didapatkan dari tabel 4.1, sehingga:

NPSHa $=(P a: \Upsilon)-(P v: \Upsilon)-h s-h l$

$$
\begin{aligned}
& =(10332: 995,7)-(238,3: 995,7)-1,50-4,428 \\
& =10,376-0,239-1,50-4,428 \\
& =\mathbf{4 , 2 0 9} \text { meter }
\end{aligned}
$$

Net positive suction head required (NPSHr)

$\mathrm{NPSHr} \quad=\sigma \times H$

Dari percobaan diketahui bahwa harga $\sigma$ menunjukkan ketergantungan terhadap $n s$ untuk pompa-pompa yang memiliki bentuk umum. Dalam hal ini $\sigma$ dapat ditentukan dengan persamaan:
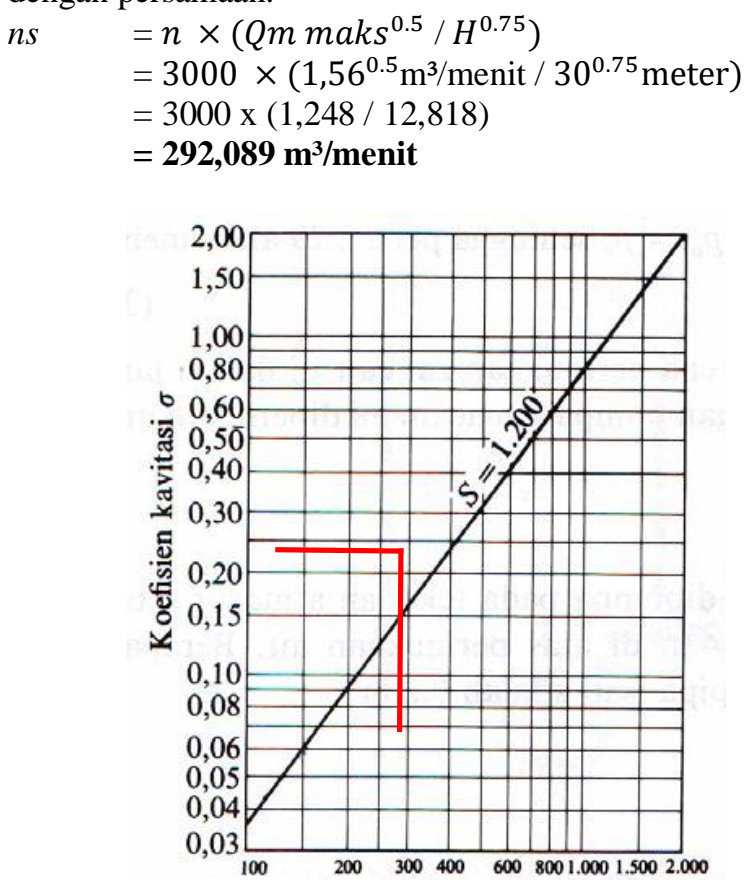

Kecepatan spesifik $n_{s}$ $\left(\mathrm{m}^{3} / \mathrm{min}, \mathrm{m}, \mathrm{rpm}\right)$

Gambar 12. Diagram Pemilihan Pompa [12]

Dari gambar 12, $n s=292,089$ untuk $\sigma=0,13$. Maka menurut Pers. (2.32), NPSH yang diperlukan adalah:

$$
\begin{aligned}
N P S H r & =\sigma \times H \\
& =0,13 \times 30 \\
& =\mathbf{3 , 9} \text { meter }
\end{aligned}
$$

Dari perhitungan NPSH diatas didapatkan; NPSHa > $N P S H r=4,209 \mathrm{~m}>3,9 \mathrm{~m}$, maka instalasi pompa tersebut aman dari kavitasi. 


\section{Kesimpulan}

Dari hasil analisa dan perhitungan yang telah dilakukan, didapatkan beberapa kesimpulan yaitu jumlah kebutuhan air bersih secara serempak besarnya adalah 31,2 $\mathrm{m}^{3} / \mathrm{jam}$ atau $250 \mathrm{~m}^{3} /$ hari dengan waktu 8 jam. Setelah melakukan perhitungan jumlah kebutuhan air bersih, volume tangki bawah (ground water tank) yang dibutuhkan adalah $84 \mathrm{~m}^{3}$, dengan dimensi P x L x T masing-masing adalah 7 x $8 \times 1,5$ meter. Untuk volume tangki atas (roof water tank) yang dibutuhkan dalam perencanaan perkiraan jangka waktu kebutuhan puncak selama 30 menit adalah $15 \mathrm{~m}^{3}$, dengan dimensi P x L x T masing-masing adalah $2 \times 5 \times 1,5$ meter, selain itu head efektif instalasi harus $30 \mathrm{~m}$. Berdasarkan hasil perhitungan head efektif instalasi maka pemilihan pompa yang direkomendasikan dalam sistem distribusi air bersih di gedung akademik ini adalah jenis pompa menggunakan sentrifugal, head $=30 \mathrm{~m}$, dan putaran $=3000 \mathrm{rpm}$.

Adapun saran-saran yang dapat diberikan adalah sebaiknya dipasang sistem control otomatis pada pompa agar dapat bekerja lebih optimal. Perhitungan bisa dilanjutkan ke tema sistem pemadam kebakaran pada bangunan gedung yang secara otomatis akan mempengaruhi volume air serta dimensi pada tangki bawah (ground water tank). Selain itu perlu adanya Standard Operation Procedure (SOP) dan Maintenance Manual guna menjaga performa pompa.

\section{Daftar Pustaka}

[1] Junia, Affiandi., Pharmawati, Kancitra., \& Nurprabowo, Anindito., "Perencanaan Sistem Instalasi Plambing Air Bersih Gedung Hotel Tebu". Jurnal Rekayasa Lingkungan Institut Teknologi Nasional Bandung. 04(02). 1-9. 2016
[2] Krisna, Andika Y., "Autocad". 2017, Diakses pada 2 Maret 2020.

[3] AutoCAD Application. AutoCAD 2013 - English.In.

[4] Badan Standardisasi Nasional. 2000. Standar Nasional Indonesia (SNI). SNI 03-6481-2000. "Sistem Plambing". Dewan Standarisasi Indonesia. Jakarta. 2000

[5] Badan Standardisasi Nasional. Standar Nasional Indonesia (SNI). SNI 03-7065-2005. "Tata Cara Perencanaan Sistem Plambing”. Dewan Standarisasi Indonesia. Jakarta. 20015

[6] Harry, Christianto.. Perancangan Sistem Distribusi Air Bersih Di Gedung Kuliah dan Laboratorium Jurusan Teknik Mesin Universitas Lampung”. Skripsi. Fakultas Teknik, Teknik Mesin, Universitas Lampung, Bandar Lampung, 2017

[7] Hanifa, Firdausi,. Konsep Rancangan dan Rencana Dasar Penyediaan Air Bersih, Penyaluran Air Buangan dan Ven Pada Gedung Solo Center Point Surakarta. Skripsi. Fakultas Teknik, Teknik Mesin, Universitas Lampung, Bandar Lampung. 2011

[8] Menteri Kesehatan Republik Indonesia,. Syarat-syarat dan Pengawasan Kualitas Air Peraturan Menteri Kesehatan Republik Indonesia No: 416/MEN.KES/PER/IX/1990. 1990

[9] Noerbambang S. M., Morimura, Takeo.. "Perancangan dan Pemeliharaan Sistem Plambing". PT. Pradnya Paramita. Jakarta. 2000

[10] SS Nisrina., Perencanaan Ulang Instalasi Pompa Air Bersih Pada Gedung Pusat Riset ITS Surabaya. Skripsi. Fakultas Vokasi, Teknik Mesin Industri, Institut Teknologi Sepuluh November, Surabaya. 2017

[11] Sularso ; Tahara, Haruo. 2006. Pompa dan Kompresor. PT. Pradnya Paramita. Jakarta.

[12] Tyler G. Hicks ; T.W. Edwards. Alih Bahasa: Zulkifli Harahap. Teknologi Pemakaian Pompa. Erlangga. Jakarta. 1996 